\title{
Examining the Arrangement of Community Food Barns in Term of Realizing Food Security in Banten Province According to Law Development Theory Perspective
}

\author{
*Rena Yulia \\ Faculty of Law \\ University of Sultan Ageng Tirtayasa \\ Banten, Indonesia \\ *rena.yulia@gmail.com
}

\author{
Aliyth Prakarsa \\ Faculty of Law \\ University of Sultan Ageng Tirtayasa \\ Banten, Indonesia \\ prakarsa79@gmail.com
}

\author{
Aan Asphianto \\ Faculty of Law \\ University of Sultan Ageng Tirtayasa \\ Banten, Indonesia \\ aan_asphianto@yahoo.co.id
}

\begin{abstract}
In realizing food sovereignty, food independence, and food security, the government establishes national food reserves consisting of government food reserves, regional government food reserves and community food reserves. The development of national food reserves is intended to anticipate shortages of food availability, excess food availability, food price volatility and/or emergency issues. The food reserves are stored in community food barns aiming to bring the food access to members closer. However, the arrangement of the community food barn itself has not made it effective as a place to store the community food reserves. Therefore, it is important to examine the effectiveness of the arrangement of food barns in providing food reserves. The study on the arrangement is observed based on law development theory perspective. The study aims to examine the arrangement of the community food barns in term of storing community food reserves. By using the normative legal research method, the inventory approach to legislation and the horizontal and vertical synchronization, the examination of the arrangement of food barns and food reserves is expected to provide an effective legal reform in realizing food security.
\end{abstract}

Keywords: food barns, food reserves, arrangement, development

\section{INTRODUCTION}

Besides clothing and shelter, food is a basic need for the human being. In Indonesia, food is identical to rice because mostly Indonesian people consume rice as basic food and the main source of carbohydrates [1].

Moreover, to maintain and preserve food consistency, food security is needed. Food security is a condition for the fulfillment of food for the state up to individuals, which is reflected in the availability of sufficient food both in quantity and quality, safe, diverse, nutritious, equitable and affordable and not contrary to the religion, beliefs, and culture of the community, for a healthy, active, and productive life in sustainable manner [2].

In the food security system in Indonesia comprehensively covers four sub-systems, namely: (i) the availability of food in sufficient quantities and types for the entire population, (ii) a smooth and equitable distribution of food, (iii) food consumption of each individual that meets adequacy of balanced nutrition, which impacts on (iv) the nutritional status of the community. Thus, the food security and nutrition do not only concern on the production, distribution, and supply of food at the macro-level (national and regional) but also involves the micro aspects. However, in daily implementation, it is often emphasized on the macro aspect that is food availability [3].

Food availability in a country is largely determined by a conducive climate condition. The prolonged dry season, the danger of flooding and various natural disasters, forest fires, especially in food crop production areas will have an impact on food availability [4]

Sustainable food security is a tangible manifestation of food independence; the effort to realize food independence is a long-term process. The opportunity to achieve food independence is quite enormous because natural resources in the form of rainfed lowland, swampy land, tidal land, and dry land are still quite wide-ranging, only if their uses are arranged proportionally and well managed and consider the food independence [5].

The policy of independence is considered the safest way to guarantee the fulfillment of food needs when compared to food procurement through imports. In its development, the policy of food independence has colored the Indonesian government's policy in agriculture since the 1970s. This can be seen from the condition of food supply, which mostly comes from the production of domestic food commodities. Currently, there is a disagreement about the concept and understanding of food self-sufficiency, food independence, food sovereignty, and food security [6].

The arrangement of food is directed at realizing food security which includes the food's availability and food reserves as well as affordable based on the community's consumption needs. The Government and communities need to nourish the national food reserves. Moreover, the Government enables to control certain food prices, both for price stabilization and to overcome the situation in case of food shortages or other emergencies. The Food Law is intended as a legal basis for the arrangement, fostering and supervision of activities or processes of production, circulation, and/or food trade. As a legal basis in the field of food, this law becomes a reference for the legislation relating to food, either the existing legal and will be created [7]. 
There has been existing arrangement concerning the management of food reserves, namely the Local Government Regulation No. 2 of 2017 on the Implementation of the Food and Governor Regulation No. 28 of 2018 on the Implementation of the Government's Food Reserves in Banten Province. The existence of food barns in Article 6 of Regional Regulation Number 2 of 2017 on Food Management is referred to as one of the strategies in implementing policies of food insecurity control, such as developing and empowering food barns.

This paper will examine the arrangement on food barns as food reserve storage in Banten province in term of realizing food security by using Mochtar Kusumaatmadja's study of Law Development Theory.

\section{METHOD}

The method conducted was using normative legal research with the inventory approach to legislation and the horizontal and vertical synchronization. The arrangements related to food availability are inventoried for the sake of examination vertically, whether any non-compliance with the regulations above or with equivalent regulations. Moreover, it was examined theoretically using Mochtar Kusumaatmadja's approach Law Development Theory.

\section{RESULT AND DISCUSSION}

The essence of national development issues is a matter of reformed ways of thinking and ways of life. Without dynamics ways of thinking and ways of life, the introduction of modern institutions will not be succeeded. If the principle has been agreed upon the sake of development, the reformed ways of thinking and ways of life shall be needed. The problem is, which values or old values that shall be replaced and preserved by the reformed values compatible in the life of today's society [8].

Mochtar Kusumaatmadja had proposed a conception of law which not only constitutes the whole principles and rules governing human life in society but includes the institutions and processes that manifest the validity of those rules in reality [9].

Law is an instrument to retain the order in society. This means that the law has nature to retain and keep what the order has been achieved. Law also plays a role in reform. This function is needed in every developing society [10].

The role of law in the development process is to ensure that changes occur in an orderly manner. [11] Both change and order are twin goals of a developing society, indeed the law becomes an instrument that must be there in the development process. [12] Law as an instrument in reformed society requires interaction to other factors in the development of society, especially economic and social factors so that in its application requires the rules and institutions.

Regarding the development in the field of economic, especially in the field of food security, the Government has regulated the Law Number 18 of 2012 on Food containing the main points of regulation including the Role of the Government and the society in realizing sufficient levels of food in the country and the diversification of food consumed is not contrary to society's belief. All of these are being held by considering the readiness and needs of the national food system.

Food security at the national level can be weakened due to several factors, namely (1) declining number and quality of natural resources, especially water resources which are the main capital of food agriculture, (2) climate change and its impact on food production, (3) infrastructure inadequate distribution, especially in remote areas, (4) inadequate regulations that guarantee an honest, responsible and safe trade system and distribution and (5) large numbers of people who have not been able to meet their food security [13].

To prevent the weakening of food security, article 23 of Law Number 18 of 2012 on Food states that in realizing food sovereignty, food independence and food security, the Government establishes national food reserves. National food reserves consist of Government food reserves, Regional Government food reserves and community food reserves. The development of national food reserves is intended to anticipate shortages of food availability, excess food availability, food price volatility and/or emergencies.

In line with this case, under the Law No. 23 of 2014 concerning the Division of Government Affairs in the field of Food, Regional Governments both Provincial and Regencies/cities are responsible for implementing the development of Government food reserves.

As for realizing food security in overcoming community's food insecurity is by storing food reserves in the food barn. Food barn is one of the institutions in the community that has long played a role in food procurement, especially in the famine season. These food barns are not only effective in serving the food needs of their members during the crisis period but also serving the financial needs to their members as result of managing the food barns [14].

Regarding the type of barns, as quoted by Muchjidin Rachmat, et al, the characteristics of community food barns are broadly divided into three types, namely: (a) individual food barns, (b) collective/group food barns and (c) village food barns. Individual food barns are a food barn owned by individual producers of basic food (rice or corn) in the form of food storage as a supply of food [15].

The community food barns are intended to bring food access closer to its members. The food barns are seen as a model of village's food security device that is quite effective as a storage area, to maintain supply stability where excess supply can reduce the price of grain, by storing, sales delays can be carried out until the better prices are received by farmers. The Central and Regional governments carry out the development of community food barn through the community empowerment by increasing the ability of human resources in managing the food barns, optimizing the existing resources and strengthening the institutional capacity. Through this empowerment, it is hoped that community food barns can be developed independently and sustainably and can perform optimally in the provision of food [16].

Food availability, both for consumption and during famine season, indeed, requires a rule or regulation in its implementation. The policy products and legislation in the field of food security in compiling the regulations have been following the benefits (utilatiarianism) as good regulations. 
Reconstruction of legal politics is carried out by analyzing various weaknesses and deviations as well as advantages both concerning behavior and regulatory texts related to food security. Start with the component of legal substance concerns on the contents of the legislation, structural components related to law formulation and law enforcement officers and culture related to the level of community compliance with the applicable law [17].

The arrangement on food was made helping to face the disaster that might be occurred. Law Number 4 of 2007 concerning Disaster Management regulates the implementation of disaster management during emergency response including meeting the basic needs, one of which is food supply assistance.

Furthermore, Government Regulation No. 17 of 2015 concerning Food Security and Nutrition in which the scope of this Government Regulation covers government food reserves and regional government food reserves, food diversification and improvement of community nutrition, food crisis preparedness and food crisis management; food distribution, food trade, and food aid, supervision, food and nutrition information systems, and community participation.

Moreover, there is a Food Security Council which is regulated in Presidential Regulation No. 83 of 2006 concerning the Food Security Council which has the task of assisting the President in formulating, evaluating and controlling policies in order to realize the national food security covering activities in the field of food supply, food distribution, food reserves, food diversity, prevention and control of food and nutrition problems.

The President also gives direct instructions related to food in the context of stabilizing the national economy, protecting the level of income of farmers, stabilizing the price of rice, securing the government rice reserves, and distributing rice for the need of purposes which set by the government as well as the continuation of the Rice Policy so that each relevant Minister, Governor and Regent/Mayor conduct the policy for the procurement of grain/rice-based in the Presidential Instruction Number 5 of 2015 concerning the Government's Grain/Rice Procurement and Rice Distribution Policy.

Trade Minister Regulation No. 04/MDAG/PER/1/2012 concerning the Use of Government Rice Reserve to Stabilize Prices also sets the associated mechanism of use of government rice reserves to the stabilize the price, monitoring, and evaluation, and reporting by the Indonesian Bureau of Logistics (PERUM BULOG).

Particularly, Banten has its own regulations related to food listed under Banten Province's Local Government Regulation No. 2 of 2017 concerning Food Management which governs policies and strategies for managing food, Food Availability, Production Development and Food Utilization, Food Affordability, Food Reserves, Food Utilization, Nutrition Improvement Pattern, Human Resource Development, Food Information System, Participation of Farmers, Obligations and Prohibitions in the production of traded rice, Monitoring and Supervision, Financing of food management, Investigation and Criminal Provisions for those who violate the provisions as regulated in this Law.
As in the provisions of Banten Province's Local Goverment Regulation Number 2 of 2017 Concerning Food Operation Chapter VI related to Food Reserves states that the Implementation of Regional Basic Food Reserves shall be carried out by the Regional Apparatus and the public can handle food affairs or BUMD (Regionally-Owned Enterprise) can handle through procurement, management and distribution.

Anticipating food insecurity, the Local Government conducts Principal Reserves given to fishermen who do not go to fishing due to bad weather, farmers affected by climate change, refugees due to natural disasters and/or social disasters, communities experiencing food insecurity, food insecurity in the aftermath of disasters or emergencies, significant changes in food price fluctuations, food raw conditions due to low consumption level standards, keep the price stability and food supply and the poor people who experience food insecurity.

Food Reserve Procurement must take note the assumption needs of consumption per household, contingency plans, poor people's needs and potential food insecurity. Food Reserve Procurement must also have criteria, namely the purchase of basic food under the price set by the government to farmers/or food or the purchase of basic food from farmers or cooperatives, and have a storage warehouse and perform the maintenance.

Related to the implementation of food reserves, it has been regulated under Banten's Governor Regulation No. 28 of 2018 concerning the Implementation of Food Reserves of Banten's Provincial Government, and it is abbreviated as CPP-Provinsi. The target recipients of CPP-Provinsi are given to Regencies/Cities' communities in Banten Province with provisions on food insecurity, post-disaster food insecurity or emergencies and food insecurity due to low consumption level standards.

Whereas for the community food reserves are food stocks controlled and managed by the community at the level of traders, communities and households. The community food reserves are stored in community food barns managed by the farming community.

Article 6 of Banten Province's Local Goverment Regulation of No. 2 of 2017 concerning the Implementation of Food regulates that in implementing the policies on handling food insecurity; one of them is a strategy to develop and empower the food barns. Afterward, it is also regulated the participation of farmers in managing the food, such as having food reserves in their food barn.

In Banten Province, some Community Food Reserves have been established. There are 126 Farmer Groups including 102 Active Farmer Groups, 8 LPM of Farmer Groups in ongoing the development process namely Wira Muda, Taruna Sakti, Tani Mukti, Tani Lestari, Mekarsari, Mekarjaya Tani, Kutakarang Mandiri, Bunga Mekar and 16 Inactive Farmer Groups e.g. Gemah Ripah, Tunas Harapan I, Tani Alam Lestari, Mekarjaya, Lebak Mandiri, Harapan Mulya, Harapan Jaya, Dwi Karya Tani, Bangkit Mandiri, Ar Rizal, Angsana I, Srimadu, Saba Tani, Laksana I, Bina Asih, and Badak Jaya [18].

However, if observing Banten's Governor Regulation No. 28 of 2018 concerning the Implementation 
of Food Reserves of the Provincial Government of Banten. So, it can be seen, the storage of food reserves is a storage warehouse, not a food barn. Thus, the calling of a storage warehouse has a different meaning to the community food brans as referred to in Law Number 18 of 2012 concerning Food and Regional Regulation of Banten's Province Number 2 of 2017 Concerning Food Management.

The process of managing food reserves is fully the responsibility of the Government, starting from the procurement, management and distribution. The mechanism for distributing food reserves can be through the delegation of the Governor to the Head of Regional Apparatus or TopDown and the proposal of Regencies/Cities or BottomUp.

Such the concept of managing food reserves cannot establish food independence for the community. Food availability intended is not produced by the community itself, but is provided by the government. In terms of government performance, this is considered good. However, it does not have a significant impact on food independence.

The arrangement of food management in Banten Province has not yet become an instrument for community change. This is because the existing arrangements are not synchronous with the main goal in term of realizing food security. Food availability should be interpreted as a community that has an adequate food supply even in emergencies or famine seasons. The condition of food availability must be created by the community itself, e.g. through food independence process, the availability of food barns with food reserves storage, and easy access to food itself.

This is different based on the arrangement of food delivery regulated in the Governor Regulation. The arrangement in this Governor Regulation tends to be in the form of food aid to the community upon famine season or food insecurity. The nature of this assistance is only temporarily recovered, so it can not realize food security fully.

The existence of food barns as a storage for food reserves in Banten Province has not been fully regulated in the governor regulation concerning on the managing of food, whereas in fact, the food barns are part of the process going through food availability. Therefore, it requires to be regulated concerning the existence of food barns as part of the storage area for community food reserves for the availability of food reserves in the event of food insecurity.

This turns out to be vital, if it is examined based on Mochtar's theory, given that the arrangement (law) must be sensitive to the development of society and that the law must be adjusted or adapted to changing circumstances. It means that custom can change due the community condition. However, the change is not just common change, yet must still have a relation with the old values [19]. Food barns were called as leuit in customary community and should preserve its existence, yet it should be adaptable to the current's community condition.

According to Mochtar's opinion, as the utilization of legal by the Government, the executive apparatus as a means of engineering society must be needed by every developing country, where the law has functioned as a mechanism that can run well to accommodate changes occurring in the community [20].

Mochtar not only conceptualized the legal from its role as an orderly regulator of social life to its function as a social engineer (for the sake of national development's realization), instead of had also "transmigrated" the process of creating legal in the interests of national development from the judicial constituency to the jurisdiction legislature which in the new order was dominated by executive authority. [21]

In connection with the concept of managing food which is regulated in the governor regulation in Banten, the regulation should become a rule of law that can regulate people's attitudes and mindset to achieve the orderly in realizing the food availability. The Government is an institution functioning to realize the availability of food in the community. The process required in the direction of food availability must be in line with the concept of food independence. Existing regulations are not following this matter, but only limited to the managing of food aid that is temporary. Thus, such arrangements can not yet become an instrument for the community changes.

To realize the development of food security, of course, rules must be established in the form of law which is a manifestation of nature, values, attitudes, mindset coming from the community itself. The changes in values held by the community, the choices of removal values, preserve the old values and the discovery of values must be following current conditions. All of which must be manifested in regulations to bring about a change in a better society.

Thus, the examining arrangement of community food barns in term of realizing food security in Banten Province based on Mochtar Kusumaatmadja's Law Development Theory Perspective has not yet fulfilled legal criteria as an instrument for community change. It can be seen from, first: the rule of law that is not yet in line with one another. Especially, the governor regulation on food management does not regulate the stored and managed food reserve in the food barns with the concept of food independence. Instead of food reserves come from the warehouses are given to target recipients with the nature of assistance from the government. It certainly cannot create food availability which is born from food independence.

Second, in realizing the food availability, the institutions involved are not only the Government but also the community and households as the smallest unit. The community is not only considered as a target that has to get food aid but it is part of an institution that works together in creating an independent food supply.

Third, the manifestation process of availability of food through food reserves should start from the customary habits of the community in storing rice in the leuit, which at current conditions is adjusted to storing rice in the granary. The attitudes and habits of these people make them always have food reserves even in times of famine or disaster.

If these three things can be realized in reality, the food security related to food availability will be able to be built up in the community by developing and empowering the community's food barns. This is where the role of law as an instrument for community change can be achieved. 


\section{CONCLUSION}

Arrangements related to food barns in Banten Province in the framework of food availability when examined from the Law Development Theory perspective have not been able to fulfill the law as an instrument for community change. That is because the arrangement is not following the concept of the manifestation of food availability based on food independence. So, the process in changing community does not run based on the values, attitudes, and mindset of the community itself. Therefore, it is necessary to change the arrangement so that it can be realized in reality in the community.

\section{ACKNOWLEDGMENT}

The writers would like to thank you for the Islamic Development Bank and Sultan Ageng Tirtayasa University.

\section{REFERENCES}

[1] Suwarno, Increasing Rice Production Towards Sustainable Food Security, FOOD, Vol. 19 No. 3, September 2010, p .234

[2] See Law Number 18 of 2012 Regarding Food Article 1 Number 4.

[3] Heri Suharyanto, Food Security, Journal of Social Humanities, Vol. 2 No. 2, November 2011, p. 187.

[4] Ibid, p. 190.

[5] Achmad M. Fagi, Indonesia's Food Security in Threats, Analysis of Agricultural Policy, Vol.11 No 1, June 2014, p. 23.

[6] Galuh Prila Dewi and Ari Mulianta Ginting, Anticipating Food Crisis through Food Diversification Policy, Journal of Economics Public Policy, Vol. 3 No. 1, June 201 2, p. 68.
[7] Moch Najib Imanullah, Politics of National Food Security Law (Study of the Political Synchronization of Law on the PVP Rights Law and the Food Law), Yustisia, Vol. 2 No. 1, April 2013, p. 97.

[8] Mochtar Kusumaatmadja, Legal Concepts in Development, PT. Alumni, Bandung, 2006, p. $10-11$.

[9] Khudzaifah Dimyati and Kelik Wardiono, Typology Legal Thought: A Thought copies of Mochtar Kusumaatmadja, Digest Epistema, Epistema Institute, Volume 2 /2012, p 13.

[10] Mochtar Kusumaatmadja , opcit , p.13-14.

[11] Ibid, p. 19.

[12] Ibid, p. 20.

[13] Sulhani Hermawan, Overview of Social Justice Against Indonesian. Code of Procedures, MIMBAR LAW, Vol 24 No. 3, October 2012, p. 499.

[14] Achmad Faqih and Neneng Rohayati, "Relationship of Rice Food Program Program with Family Food Security (Study Case in the Group Food Barn, Ciwaringin District, Cirebon Regency) ", Agrijati Journal Vol 28 Number 1, April 2015, p. 175.

[15] Muchijidin Rachmat, et al, Community Food Barns: Its Existences and Roles in Relief Food Insecurity, Economics Agro of Research Forum, Vol 29, No 1, Me i 2011, p.49.

[16] http://bkp.pertanian.go.id/pengembangan-lumbungpangan-masyarakat accessed March 14, 2019.

[17] Eri Hendro Kusuma, Political Law of Environmental Protection in Domestic Crop Commodities, Scientific Journal of Pancasila and Citizenship Education, Year 1 No. 1, June 2016, page 35.

[18] http://sicdp.bantenprov.go.id/profil/lpm accessed 27 August 2019 .

[19] Khudzaifah Dimyati and Kelik Wardi ono, opcit, p. 13.

[20] Malik, Reading Back Legal Theory Development, Digest Epistema, Epistema Institute, Volume 2 /2012 Google Translation, p 35.

[21] Ibid, p. 35 